\title{
Evidence for spatial structure and directional gene flow in a population of an aquatic plant, Potamogeton coloratus
}

\author{
RICHARD J . GORNALL*, PETER M. HOLLINGSWORTH† \& CHRISTOPHER D. \\ PRESTON: \\ Department of Botany, University of Leicester, Leicester LE1 7RH, †Division of Environmental and Evolutionary \\ Biology, University of Glasgow, Glasgow G12 8QQ and ‡Institute of Terrestrial Ecology, Monks Wood, Abbots \\ Ripton, Huntingdon PE17 2LS, U.K.
}

\begin{abstract}
Six hundred and forty-seven samples of Potamogeton coloratus from 60 ditches in the Gordano Valley, Somerset were analysed for variation at two polymorphic PGM isozyme loci using starch gel electrophoresis. A total of eight genotypes was detected, and a high level of partitioning of genetic variability between ditches was observed with $F_{\mathrm{ST}}=0.575$. Genetic variability was shown to increase with distance from the head of the valley. The genetic subdivision of the population and pattern of increasing diversity downstream and downwind were attributed to genetic bottlenecks, associated with ditch cleaning events, and subsequent directional gene flow mediated by the prevailing wind and water currents.
\end{abstract}

Keywords: aquatic plant, gene flow, isozymes, population structure, Potamogeton, Potamogetonaceae.

\section{Introduction}

Studies of gene flow in aquatic plant species have dealt with range extensions (Cook, 1985), aspects of long-distance dispersal (Ridley, 1930; Vlaming \& Proctor, 1968), genetic differentiation between populations (Laushman, 1993) and the relationship of genetic to geographical distances between populations (Barrett et al., 1993; Hollingsworth et al., 1996). Very little attention has been paid, however, to substructuring within populations of aquatic macrophyte species. Only Zostera marina L. and Vallisneria americana Michx. have been studied in any detail. Laushman (1993) found a high level of subdivision $\left(G_{\mathrm{ST}}=0.295\right)$ in a population of $Z$. marina, involving geographical partitioning of two PGM alleles. Ruckelshaus (1996) reported a slightly lower level $\left(F_{\mathrm{ST}}=0.154\right)$, also based on PGM loci, in a second population of this species. In contrast, little subdivision for isozyme loci was found in a population of $V$. americana in which $F_{\mathrm{ST}}=0.029$ (Lokker $e t$ al., 1994), despite the fact that the female-male ratio increased with depth of water (Laushman, 1993).

*Correspondence. E-mail: rjg@leicester.ac.uk
Even less attention has been paid to the actual dynamics of gene flow in such aquatic plant populations. In particular, the extent to which flowing water may promote unidirectional gene flow is unknown, and it is difficult to predict the likely pattern of differentiation within a particular stream or river. Clearly, it could depend on a number of factors, including the genetic diversity of upstream subpopulations and, in the case of perennials, the extent of clonal growth; in aerial-flowering species, the behaviour of biotic pollinators or wind direction will also have a bearing. The available experimental evidence is sparse and equivocal. For example, in an isozyme study of the pattern of genetic differentiation among populations of the clonal perennial herb Mimulus caespitosus Greene growing in and by the side of watercourses in the Washington Cascades, Ritland (1989) found no sign of unidirectional gene flow within streams. In contrast, a study by Hill et al. (1978) of the genetic make-up of populations of three amphibious, shrubby legumes growing on the banks of rivers in Brazil produced some qualitative indication that water flow might influence genetic structure.

Barrett et al. (1993) pointed out that there is little theoretical work on which to base predictions and 
posed the question of whether dispersal is random with respect to distance in running water. In particular, are downstream populations more or less variable than upstream populations? In this study, we investigate the role that directional gene flow may play in determining the genetic structure of a population of the aquatic macrophyte, Potamogeton coloratus Hornem., growing in the Gordano Valley, near Bristol, U.K.

\section{Materials and methods}

\section{Potamogeton coloratus}

Potamogeton coloratus is an aquatic macrophyte, which grows in shallow, base-rich but nutrient-poor water. It is an anemophilous, self-compatible (sometimes autogamous) perennial, which usually sets copious seed but can also spread by means of rhizomatous growth (Hollingsworth et al., 1995). A recent study of the species in Britain showed that nine out of 12 populations studied were monomorphic for the same 14-locus isozyme genotype (Hollingsworth et al., 1995). Variation within populations was found at only two localities, Wicken Fen and Gordano Valley, both of which have a long postglacial history as wetlands. The latter population was the more variable, with diallelic variation detected at each of two PGM loci, and this site is the focus of the present study.

\section{The Gordano Valley}

The Gordano Valley (Ordnance Survey grid reference ST47) is a well-defined, wedge-shaped basin about $1.5 \mathrm{~km}$ wide and $7.5 \mathrm{~km}$ long, orientated from the south-west to the north-east and bounded by hills up to $70-130 \mathrm{~m}$ high. The prevailing winds and water flow are from the head of the valley in the south-west (Heathwaite, 1990). The plant ecology and the late- and postglacial history of the locality have been summarized by Willis \& Jefferies (1959) and Jefferies et al. (1968), and there is also information available on land management practices over the last 200 years (Willis \& Jefferies, 1959; Heathwaite, 1990; T. Robinson, pers. comm.). The valley has extensive peat deposits and a high groundwater table fed by rainfall and springs. Historically (and possibly naturally), the valley has been drained by three streams running the length of the basin, and the valley bottom has been used as watermeadows or pastureland at various times. Before 1815 , extensive flooding sometimes occurred, but in the early nineteenth century a network of drainage ditches (known locally as rhynes) was dug, each $c$.
$1.5 \mathrm{~m}$ deep $\times 2 \mathrm{~m}$ across. It is in these that $P$. coloratus grows. Considerable changes to the drainage network occurred during 1830-1900 as a result either of deliberate rationalization or of neglect: whatever the cause, far fewer ditches were present in 1904 than in 1830. The drainage system degenerated further in the period up to about 1946, with the loss of more ditches, and winter flooding became a regular feature of the valley again ( $\mathrm{T}$. Robinson, pers. comm.). After this point, however, all the original ditches that had been dug in the early nineteenth century were reinstated as part of the postwar effort to increase agricultural production and, by the 1960s, a very extensive network existed. Only a slight loss has occurred since then. Much of the valley was adopted as a National Nature Reserve in 1987, but it is still used for grazing. A detailed record of ditch maintenance since 1985/86 has been kept by the staff of English Nature, which manages the site. The cleaning programme has involved four levels of increasing thoroughness: (1) hand weeding with rakes and spades; (2) mechanical weeding by means of a Bradshaw Bucket; and (3) and (4) reprofiling, during which all, or almost all, plant material is scoured from one side (3) or both sides (4) and the bottom of a ditch using a mechanical excavator.

\section{Sampling}

A total of 647 leaves was collected from 60 separate ditches in 1994. An attempt was made to sample from every 'individual' plant. A minimum distance of $2 \mathrm{~m}$ between sampled sites was maintained to try to avoid collecting leaves emanating from the same rhizome. The modal sampling interval, accounting for $39 \%$ of our sites, was $4-6 \mathrm{~m}$. All ditches within the reserve were visited. The location from which each leaf was collected was recorded to the nearest metre and plotted on a 1:5000 scale map. For our purposes, ditches were delimited by their intersections with other ditches, which often meant that continuous stretches of water were subdivided. Ditches were named according to their approximate polar orientation and the field they bounded. Thus, ditch $3 \mathrm{cS}$ is the ditch running along the southern edge of field $3 c$ (Fig. 1a). The field code numbers are those assigned by English Nature.

\section{Electrophoresis}

Material was returned to the laboratory and stored at $4^{\circ} \mathrm{C}$. Isozyme electrophoresis of the material, using $12 \%$ starch gels, was carried out within 5 days of collection, using the protocol described by Hollingsworth et al. (1995). All samples were 

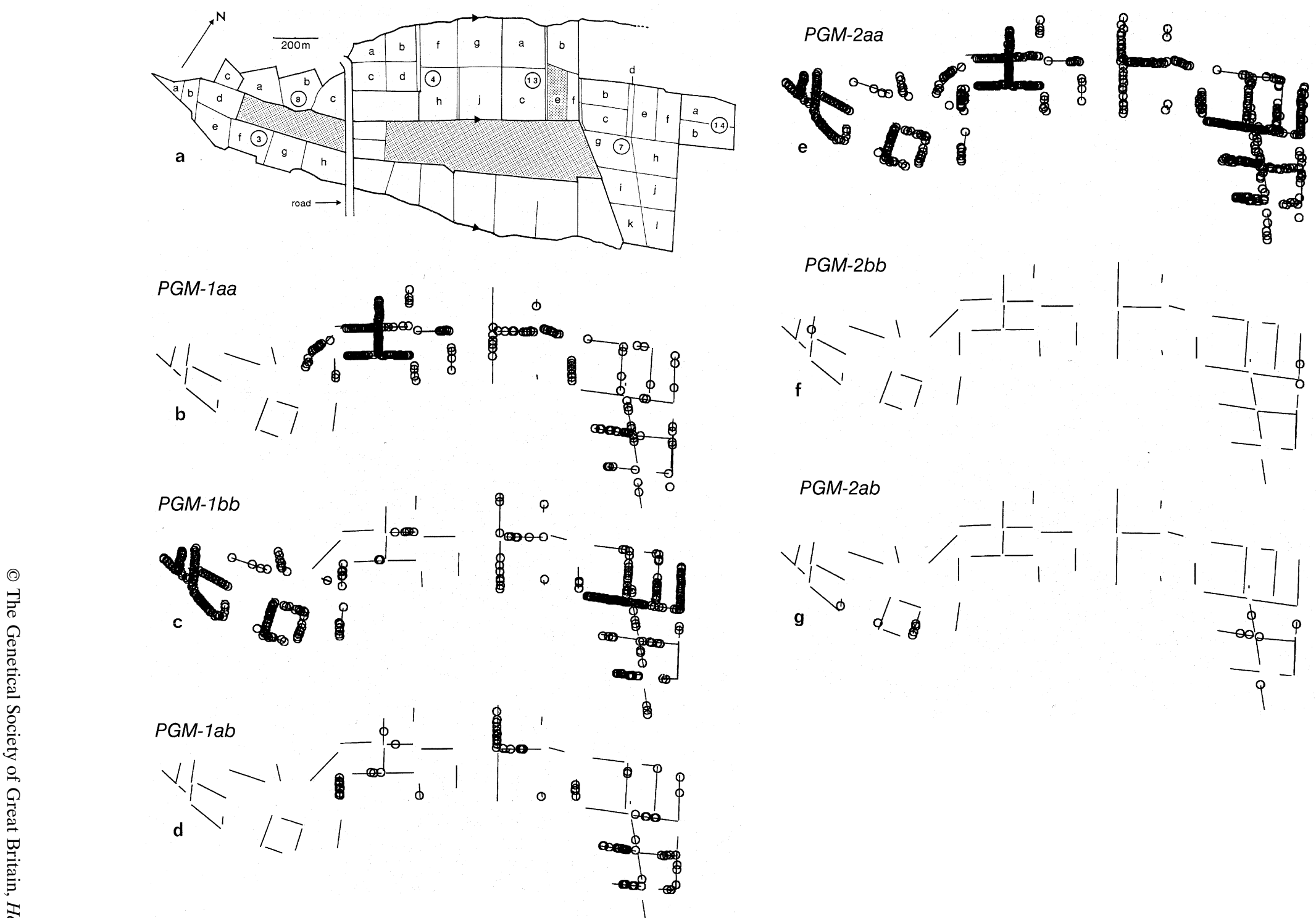

난

Fig. 1 Maps of Gordano Valley showing the system of interconnected ditches and distribution of PGM genotypes of Potamogeton coloratus. (a) Field codes, o road, woodland (shaded) and principal streams (arrowed with direction of flow); zone $1=$ ditches bounding fields in group 3 (except ditch $3 \mathrm{cS}$ ), zone $2=$ ditches bounding fields in group 8 plus ditch $3 \mathrm{cS}$, zone $3=$ ditches bounding fields in groups 4 and 13 , zone $4=$ ditches bounding fields in groups 7 and 14. (b-g) Spatial distribution of single-locus $P G M$ genotypes, plotted as circles. Ditches from which samples were taken are shown as lines. (b) $P G M-1 a a$

t homozygotes. (c) $P G M-1 b b$ homozygotes. (d) PGM-1ab heterozygotes. Note that $P G M$-1a scarcely overlaps with $P G M-1 b$ in the upper part of the valley. (e) PGM-2aa homozygotes. (f) PGM-2bb homozygotes. (g) PGM-2ab heterozygotes. 
analysed for variation at the two polymorphic $P G M$ loci.

\section{Data analysis}

Estimates of breeding behaviour were based on comparisons with data expected under Hardy-Weinberg equilibrium using a correction for small sample sizes (Levene, 1949). For each ditch, the heterozygosity expected under Hardy-Weinberg equilibrium for each locus was calculated as $H=1-\Sigma p_{i}^{2}$, where $p_{i}$ is the frequency of the $i$ th allele. The mean heterozygosity or gene diversity $\left(H_{\mathrm{D}}\right)$ in each ditch was then found by averaging $H$ over the two polymorphic loci. The number of multilocus (effectively $P G M$ two-locus) genotypes per ditch was also recorded and used to calculate genotypic diversity as $G=1-\Sigma g_{i}^{2}$, where $g_{i}$ is the frequency of the $i$ th genotype.

The partitioning of genetic variability within and between the 60 ditches was estimated using Wright's $F$-statistics (Wright, 1965, 1978; Nei, 1977) as calculated by BIOSYs-1 (Swofford \& Selander, 1981). To examine the effects of the potential physical barriers to gene flow imposed not only by the ditches but also by the woodland and the road at the site, a hierarchical analysis using $F$-statistics was carried out. Data from ditches were pooled into zones, separated from one another by woodland or the road. The boundaries of the zones are defined in Fig. 1a. The $F$-statistics are related in the following way:

$$
\left(1-F_{\mathrm{IT}}\right)=\left(1-F_{\mathrm{ID}}\right)\left(1-F_{\mathrm{DZ}}\right)\left(1-F_{\mathrm{ZT}}\right)
$$

where $F$-values are fixation indices of individuals (I), ditches (D) and zones (Z) relative to each other and to the total $(\mathrm{T})$ population, as indicated (Wright, 1978). These values can be related to the diversity indices of Nei (1975), such that the proportion of gene diversity stored within ditches is mean $H_{\mathrm{D}} / H_{\mathrm{T}}=1-F_{\mathrm{DT}}$, that stored between ditches relative to zones is $D_{\mathrm{DZ}} / H_{\mathrm{T}}=\left(F_{\mathrm{DT}}-F_{\mathrm{ZT}}\right)$ and that stored between zones (separated from one another by woodland or the road) relative to the total is $D_{\mathrm{ZT}} / H_{\mathrm{T}}=F_{\mathrm{ZT}} . F_{\mathrm{XY}}$-values were adjusted for sample size by subtracting $1 / 2 N$, the sampling variance of $F_{\mathrm{XY}}$ (Nei \& Imaizumi, 1966). A chi-squared test was used to test the statistical significance of $F_{\mathrm{XY}}$-values: $\chi^{2}=2 N F_{\mathrm{XY}}(k-1)$, with $(k-1)(j-1)$ d.f., where $N$ is the total sample size, $k$ is the number of alleles for the locus and $j$ is the number of populations studied (Workman \& Niswander, 1970).

To test for the existence of directional gene flow, the gene and genotypic diversity of each ditch were tested for their correlation with the geographical distance of the ditch from the head of the valley. The latter parameter was calculated by projecting the midpoint of the ditch onto the longitudinal axis of the valley and measuring from that point.

In order to assess the impact of ditch cleaning on genetic variability, detailed data on the weeding history of each ditch every winter since 1985/86 were obtained from English Nature. The relationship between genetic variability and weeding method was tested by Kruskal-Wallis analysis of variance (owing to the non-normality of the data). The correlation between genetic variability and the cumulative effect of weeding was also investigated. A score $(W)$ was attributed to each type of weeding method as follows: $1=$ hand weeding; $2=$ mechanical weeding; $3=$ one side of ditch reprofiled; $4=$ both sides of ditch reprofiled, in order of increasing effectiveness. An estimate of the cumulative effect of weeding (the cleaning index) since 1985/86 on each of our sampled ditches was calculated as the weeding score $(W)$ for a particular year divided by the number of years since the work was undertaken, summed over the 10 years since 1985/86.

\section{Results}

The observed genotype frequencies in each ditch are given in Table 1. Both alleles for PGM-1 were relatively common, but by far the most common allele for PGM-2 was $a$ with only three $b b$ and $12 a b$ genotypes detected out of the 647 plants analysed. A total of eight multilocus genotypes was observed out of a possible nine combinations of the two alleles at the two loci examined. (PGM-1ab, PGM-2bb was the only genotype not recovered.)

Of the 60 ditches sampled, $33(55 \%)$ were polymorphic, with $12(20 \%)$ of these showing significant deviations from Hardy-Weinberg equilibrium at one locus (Table 1). All deviations from Hardy-Weinberg were caused by an excess of homozygotes, except for one ditch, $4 \mathrm{gE}$, which showed an excess of heterozygotes for $P G M-1$.

The distribution of the alleles in the different ditches is shown in Fig. 1(b-g). Most notably, ditches towards the head of the valley bordering fields $3 \mathrm{a}-\mathrm{h}$ and $8 \mathrm{a}$ are fixed for $P G M-1 b$, whereas those bordering fields $4 \mathrm{a}-\mathrm{j}$ and $8 \mathrm{c}$ are either fixed for, or almost entirely dominated by, PGM-1a. In contrast, both alleles are common in ditches bordering field groups 13 and 7, lower down the valley. Substantial substructuring of the population of $P$. coloratus in the Gordano Valley was also indicated by Wright's $F$-statistics (Table 2). In terms of Nei's 
Table 1 Genetic variability at two PGM loci of Potamogeton coloratus for all ditches

\begin{tabular}{|c|c|c|c|c|c|c|}
\hline \multicolumn{2}{|c|}{ Zone/ditch } & \multirow[b]{2}{*}{$N$} & \multirow[b]{2}{*}{ 2-locus $P G M$ genotypes } & \multirow{2}{*}{$\begin{array}{c}\text { Genotype } \\
\text { diversity, } G\end{array}$} & \multicolumn{2}{|c|}{ Mean heterozygosity } \\
\hline No. & Code & & & & $H_{\mathrm{O}}$ & $H_{\mathrm{D}}^{*}$ \\
\hline $1 / 1$ & $3 \mathrm{aS}$ & 12 & bbaa 12 & 0 & 0 & 0 \\
\hline $1 / 2$ & $3 \mathrm{eW}$ & 8 & bbaa 8 & 0 & 0 & 0 \\
\hline $1 / 3$ & $3 \mathrm{dW}$ & 12 & bbaa $11, b b b b 1$ & 0.153 & $0 \dagger$ & $0.080(0.080)$ \\
\hline $1 / 4$ & $3 b S$ & 4 & bbaa 4 & 0 & 0 & 0 \\
\hline $1 / 5$ & $3 \mathrm{bW}$ & 21 & bbaa 21 & 0 & 0 & 0 \\
\hline $1 / 6$ & $3 \mathrm{dS}$ & 17 & bbaa 17 & 0 & 0 & 0 \\
\hline $1 / 7$ & $3 \mathrm{eE}$ & 3 & bbaa $2, b b a b 1$ & 0.444 & $0.167(0.167)$ & $0.167(0.167)$ \\
\hline $1 / 8$ & $3 \mathrm{eS}$ & 21 & bbaa 21 & 0 & 0 & 0 \\
\hline $1 / 9$ & $3 \mathrm{fS}$ & 1 & bbaa 1 & 0 & 0 & 0 \\
\hline $1 / 10$ & $3 \mathrm{gE}$ & 8 & bbaa 3, bbab 5 & 0.469 & $0.313(0.313)$ & $0.229(0.229)$ \\
\hline $1 / 11$ & $3 \mathrm{gN}$ & 8 & bbaa 8 & 0 & 0 & 0 \\
\hline $1 / 12$ & $3 \mathrm{gS}$ & 7 & bbaa $6, b b a b 1$ & 0.245 & $0.071(0.071)$ & $0.071(0.071)$ \\
\hline $1 / 13$ & $3 \mathrm{gW}$ & 24 & bbaa 24 & 0 & 0 & 0 \\
\hline $1 / 14$ & $3 \mathrm{hE}$ & 6 & bbaa 6 & 0 & 0 & 0 \\
\hline $2 / 15$ & $3 \mathrm{cS}$ & 1 & bbaa 1 & 0 & 0 & 0 \\
\hline $2 / 16$ & $8 \mathrm{aS}$ & 3 & bbaa 3 & 0 & 0 & 0 \\
\hline $2 / 17$ & $8 \mathrm{bS}$ & 1 & bbaa 1 & 0 & 0 & 0 \\
\hline $2 / 18$ & $8 \mathrm{bW}$ & 6 & bbaa 6 & 0 & 0 & 0 \\
\hline $2 / 19$ & $8 \mathrm{cE}$ & 19 & aаaа 4, abaa 9, bbaa 6 & 0.632 & $0.237(0.237)$ & $0.254(0.254)$ \\
\hline $2 / 20$ & $8 \mathrm{cS}$ & 1 & bbaa 1 & 0 & 0 & 0 \\
\hline $2 / 21$ & $8 \mathrm{cW}$ & 14 & aаaа 14 & 0 & 0 & 0 \\
\hline $3 / 22$ & $4 \mathrm{aS}$ & 25 & aаaа 25 & 0 & 0 & 0 \\
\hline $3 / 23$ & $4 \mathrm{bS}$ & 11 & aаaа 5, abaa 1, bbaa 5 & 0.579 & $0.045 \dagger(0.045)$ & $0.262(0.262)$ \\
\hline $3 / 24$ & $4 \mathrm{bW}$ & 20 & aaaa 19, abaa 1 & 0.095 & $0.025(0.025)$ & $0.025(0.025)$ \\
\hline $3 / 25$ & $4 \mathrm{cS}$ & 23 & aaaa 18, abaa 3, bbaa 2 & 0.363 & $0.065 \dagger(0.065)$ & $0.132(0.132)$ \\
\hline $3 / 26$ & $4 \mathrm{dS}$ & 17 & aаaa 17 & 0 & 0 & 0 \\
\hline $3 / 27$ & $4 \mathrm{dW}$ & 20 & aаaa 20 & 0 & 0 & 0 \\
\hline $3 / 28$ & $4 \mathrm{fS}$ & 7 & aаaа 7 & 0 & 0 & 0 \\
\hline $3 / 29$ & $4 \mathrm{fW}$ & 5 & aaaa 5 & 0 & 0 & 0 \\
\hline $3 / 30$ & $4 \mathrm{gE}$ & 14 & abaa 11, bbaa 3 & 0.337 & $0.393 \dagger(0.393)$ & $0.247(0.247)$ \\
\hline $3 / 31$ & $4 \mathrm{hW}$ & 5 & aaaa 4, abaa 1 & 0.320 & $0.100(0.100)$ & $0.100(0.100)$ \\
\hline $3 / 32$ & $4 \mathrm{jE}$ & 12 & aaaa 3, abaa 1, bbaa 8 & 0.486 & $0.042 \dagger(0.042)$ & $0.216(0.216)$ \\
\hline $3 / 33$ & $4 \mathrm{jW}$ & 4 & aaaa 4 & 0 & 0 & 0 \\
\hline $3 / 34$ & $13 \mathrm{aE}$ & 2 & aaaa 1, bbaa 1 & 0.500 & 0 & $0.333(0.333)$ \\
\hline $3 / 35$ & $13 \mathrm{aS}$ & 31 & aаaа 18, abaa 7, bbaa 6 & 0.574 & $0.113 \dagger(0.113)$ & $0.216(0.216)$ \\
\hline $3 / 36$ & $13 \mathrm{cE}$ & 2 & $a b a a 1, b b a a 1$ & 0.500 & $0.250(0.250)$ & $0.250(0.250)$ \\
\hline $3 / 37$ & $13 \mathrm{eN}$ & 7 & aаaа 7 & 0 & 0 & 0 \\
\hline $3 / 38$ & $13 \mathrm{fE}$ & 12 & aaaa 7, abaa 3, bbaa 2 & 0.569 & $0.125(0.125)$ & $0.216(0.216)$ \\
\hline $3 / 39$ & $13 \mathrm{fN}$ & 1 & aаaа 1 & 0 & 0 & 0 \\
\hline $4 / 40$ & $7 \mathrm{bE}$ & 10 & aaaa 2, abaa 1, bbaa 7 & 0.460 & $0.050 \dagger(0.050)$ & $0.197(0.197)$ \\
\hline $4 / 41$ & $7 \mathrm{bN}$ & 3 & aaaa 1, bbaa 2 & 0.444 & 0 & $0.267(0.267)$ \\
\hline $4 / 42$ & $7 \mathrm{cE}$ & 8 & aaaa 2, bbaa 6 & 0.375 & $0 \dagger$ & $0.200(0.200)$ \\
\hline $4 / 43$ & $7 \mathrm{dE}$ & 2 & bbaa 2 & 0 & 0 & 0 \\
\hline $4 / 44$ & $7 \mathrm{eE}$ & 23 & aaaa $1, a b a a$ 1, bbaa 21 & 0.163 & $0.022(0.022)$ & $0.062(0.062)$ \\
\hline $4 / 45$ & $7 \mathrm{eN}$ & 4 & $a a a a 2, b b a a 2$ & 0.500 & 0 & $0.286(0.286)$ \\
\hline $4 / 46$ & $14 \mathrm{bW}$ & 13 & aаaа 1, bbaa 12 & 0.142 & $0 \dagger$ & $0.074(0.074)$ \\
\hline $4 / 47$ & $14 \mathrm{aW}$ & 13 & aaaa 2, abaa 2, bbaa 9 & 0.473 & $0.077(0.077)$ & $0.185(0.185)$ \\
\hline $4 / 48$ & $7 \mathrm{gN}$ & 26 & bbaa 26 & 0 & 0 & 0 \\
\hline $4 / 49$ & $7 \mathrm{gS}$ & 35 & aaaa $16, a b a a 12, b b a a 4, a b a b 3$ & 0.653 & $0.257(0.171)$ & $0.265(0.182)$ \\
\hline $4 / 50$ & $7 \mathrm{hE}$ & 5 & $a a b b 1, a a a b 1, b b a a 3$ & 0.560 & $0.100 \dagger(0.100)$ & $0.500(0.033)$ \\
\hline $4 / 51$ & $7 \mathrm{eS}$ & 17 & aaaa 2, abaa 4, bbaa 11 & 0.512 & $0.118(0.118)$ & $0.185(0.185)$ \\
\hline $4 / 52$ & $7 \mathrm{fS}$ & 5 & $a b a a 1, b b a a 4$ & 0.320 & $0.100(0.100)$ & $0.100(0.100)$ \\
\hline $4 / 53$ & $7 \mathrm{hS}$ & 12 & aaaa 1, abaa $5, b b a a 6$ & 0.569 & $0.208(0.208)$ & $0.216(0.216)$ \\
\hline
\end{tabular}


Table 1 Continued

\begin{tabular}{|c|c|c|c|c|c|c|}
\hline \multicolumn{2}{|c|}{ Zone/ditch } & \multirow[b]{2}{*}{$N$} & \multirow[b]{2}{*}{ 2-locus $P G M$ genotypes } & \multirow{2}{*}{$\begin{array}{c}\text { Genotype } \\
\text { diversity, } G\end{array}$} & \multicolumn{2}{|c|}{ Mean heterozygosity } \\
\hline No. & Code & & & & $H_{\mathrm{O}}$ & $H_{\mathrm{D}}^{*}$ \\
\hline $4 / 54$ & $7 \mathrm{hW}$ & 10 & aaaa 5, abab 1, bbaa 4 & 0.580 & $0.100 \dagger(0.000)$ & $0.311(0.211)$ \\
\hline $4 / 55$ & $7 \mathrm{iS}$ & 23 & aaaa 4 , abaa 8, bbaa 11 & 0.620 & $0.174(0.174)$ & $0.232(0.232)$ \\
\hline $4 / 56$ & $7 \mathrm{jE}$ & 5 & aaaa 1, abaa 3, aabb 1 & 0.560 & $0.300(0.300)$ & $0.411(0.056)$ \\
\hline $4 / 59$ & $7 \mathrm{lE}$ & 2 & aaaa 2 & 0 & 0 & 0 \\
\hline $4 / 60$ & $71 \mathrm{~W}$ & 5 & aaaa 1, bbaa $3, a a a b 1$ & 0.560 & $0.100 \dagger(0.100)$ & $0.367(0.167)$ \\
\hline
\end{tabular}

$N$, sample size per locus; the genotype for $P G M-1$ is followed by that for $P G M-2 . H_{\mathrm{O}}$, mean observed heterozygosity; $H_{\mathrm{D}}$, mean expected heterozygosity under Hardy-Weinberg equilibrium (gene diversity). Standard errors in parentheses.

*Unbiased estimate (see Nei, 1978).

$\dagger$ Polymorphic loci showing significant deviation from Hardy-Weinberg equilibrium $(P<0.05)$, using exact probability.

diversity indices, $46 \%$ of the variation is stored within ditches, $22 \%$ is partitioned between ditches relative to zones (areas separated by woodland or the road) and $32 \%$ is attributable to differentiation between zones. When ditches are considered as populations, the mean overall inbreeding coefficient $\left(F_{\text {IT }}=0.749\right)$ receives a greater contribution from subdivision between ditches $\left(F_{\mathrm{DT}}=0.575\right)$ than from inbreeding within ditches $\left(F_{\mathrm{ID}}=0.408\right)$. Lower values of all three $F$-statistics were found for $P G M-2$ than for $P G M-1$, a result attributable to the rarity of the $P G M-2 b$ allele.
The genetic diversity per ditch showed a general increase from the top (south-western) end of the valley to the bottom (north-eastern) end. This was reflected in the highly significant correlation between the distance of a ditch downstream from the head of the valley and its constituent genetic variability, measured as either gene or genotype diversity (Table 3 ). There was no significant difference between ditches that had been cleaned in different ways in either gene diversity (KruskalWallis statistic $=1.493, P>0.9,5$ d.f.) or genotype diversity (Kruskal-Wallis statistic $=2.185, P>0.75,5$

Table $2 F$-statistics (Wright, 1978) calculated for each PGM locus of Potamogeton coloratus, combined across loci, by ditch (D) (columns 2-4); hierarchical $F$-statistics by ditch and by zone (Z) (columns 5-7)

\begin{tabular}{|c|c|c|c|c|c|c|}
\hline \multirow[b]{2}{*}{ Locus } & \multicolumn{3}{|c|}{$F$-statistics by ditch } & \multicolumn{3}{|c|}{$F$-statistics by ditch by zone } \\
\hline & $F_{\mathrm{ID}}$ & $F_{\mathrm{DT}}$ & $F_{\text {IT }}$ & $F_{\mathrm{DZ}}$ & $F_{\mathrm{ZT}}$ & $F_{\mathrm{DT}}$ \\
\hline$P G M-1$ & 0.449 & $0.610^{* * *}$ & 0.785 & 0.356 & $0.348^{* * *}$ & 0.580 \\
\hline$P G M-2$ & 0.193 & $0.195^{* * *}$ & 0.350 & 0.119 & $0.004 \mathrm{NS}$ & 0.123 \\
\hline Mean & 0.408 & $0.575^{* * *}$ & 0.749 & 0.326 & $0.319 * * *$ & 0.542 \\
\hline
\end{tabular}

$* * * P<0.001$.

Table 3 Spearman rank-order correlation coefficients between measures of genetic variability of Potamogeton coloratus in each ditch and the distance from the head of the valley and the severity of weeding (cleaning index)

\begin{tabular}{lll}
\hline Ditch parameter & Gene diversity $\left(H_{\mathrm{S}}\right)$ & Genotype diversity $(G)$ \\
\hline Distance from head of valley & $r=0.561, P<0.0001$ & $r=0.553, P<0.0001$ \\
Cleaning index & $r=0.044, P=0.739$ & $r=0.027, P=0.841$ \\
\hline
\end{tabular}

(C) The Genetical Society of Great Britain, Heredity, 80, 414-421. 
d.f.); nor was there any significant correlation of these two parameters with the cumulative effects of weeding (cleaning index; Table 3), other than that those ditches with a regime of frequent reprofiling usually had no pondweeds at all.

\section{Discussion}

The overall mean value of $F_{\mathrm{ID}}(0.408)$ and the deviations from Hardy-Weinberg equilibrium resulting from excess homozygotes in many ditches indicate that inbreeding may be occurring within ditches. Caution is necessary in the interpretation of these statistics, however, because it is not clear to what extent clonal growth, which violates the mixedmating model, will have distorted the estimates. The quantitative estimation of such vegetative growth is the subject of a future paper (in preparation), but preliminary data from spatial autocorrelation analysis, along with field observations, indicate that clonal growth is undoubtedly important as a means of both reproduction and dispersal in this population. It is likely, for instance, that the marked differentiation of adjacent ditches that often occurs (e.g. 8bW and $8 \mathrm{cW}$ ) results from the successful establishment and propagation of a single but different clone in each ditch.

From the maps (Fig. 1) and the $F_{\mathrm{XY}}$-values (Table 2 ), it is clear that the distribution of genetic variability is highly structured within the population of $P$. coloratus in the Gordano Valley. The most striking features of the pattern of variability are that upstream ditches are fixed, or nearly so, for different alleles and that genetic diversity increases towards the north-eastern end of the site, downstream and downwind from the head of the valley. The $F_{\mathrm{XY}^{-}}$ value relating to variability between zones indicates that the potential physical barriers to gene flow, i.e. the road and the woods, may play some part in this substructuring. However, the nature of the geographical pattern and the fact that even adjacent ditches can maintain separate genotypes suggest that other factors are at work.

A possible explanation for the nonrandom distribution of genetic variability could involve selection. Although isozyme variation is usually believed to be adaptively neutral (Kimura, 1968), in the present case the different $P G M-1$ alleles, which show more geographical partitioning than those at $P G M-2$, may be linked to a locus that is subject to selective pressures. In this regard, it is known that the different weeding methods used to maintain drainage ditches can affect the population biology of the constituent species (Beltman, 1984) and, by extension, could affect genotype frequencies. However, we found no significant difference between ditches that had been cleaned in different ways in either gene or genotype diversity. And nor were these two estimates of genetic variability correlated with a cumulative measure of ditch cleaning over the last 10 years. All of which indicates that any selection resulting from weeding is not the proximal cause of the pattern we found.

Our preferred explanation involves a combination of the management history of the site and the direction of the prevailing wind and water currents. Theoretical work summarized by McCauley (1991) and Ibrahim et al. (1996) has shown that colonization and extinction events can promote local genetic differentiation. Each ditch at the site is weeded approximately every 10-15 years, with the more important ones experiencing much more frequent cleaning. These cleaning events, if they do not exterminate the species completely, are likely to cause genetic bottlenecks (a few fruits and some vegetative tissue, such as rhizomes, may survive). Furthermore, because a newly cleaned ditch presents areas suitable for recolonization by plant material from elsewhere as well as from any seed bank, founder effects are likely. If ditches at the head of the valley have a reduced genetic diversity because of bottlenecks or founder effects, replenishment by alleles carried from other parts of the site up the valley against the prevailing wind and water flow is unlikely. Consequently, such ditches are likely to become fixed for particular alleles, even a particular genotype, especially if there is marked clonal growth. This is indeed the situation we found in the upper part of the valley where ditches bordering fields $3 \mathrm{a}-\mathrm{h}$ and $8 \mathrm{a}$ are fixed for allele $P G M-1 b$ (Fig. 1c) and those bordering fields $4 \mathrm{a}-\mathrm{j}$ and $8 \mathrm{c}$ are fixed for or dominated by $P G M-1 a$ (Fig. 1b). In contrast, if ditches towards the lower end of the valley lose genetic diversity when being cleaned, they stand a good chance of having alleles reintroduced by genotypes migrating down from the head of the valley on the prevailing wind and water currents. We suggest, therefore, that the greater variability that is found in field groups 7 and 13 (whose ditches contain high frequencies of both $P G M-1 a$ and $P G M-1 b)$ in the lower part of the valley is best explained by immigration from upstream, upwind sites, such as field groups 3 (fixed for $P G M-1 b$ ) and 4 (many ditches fixed for $P G M-1 a$ ). In other words, the prevailing wind and water currents appear to result in effective directional gene flow down the valley. The fact that there may be significant levels of inbreeding suggests to us that gene flow occurs primarily by means of 
fruits or vegetative fragments travelling in the water, rather than by means of pollen drifting in the air currents. (There are also significant potential barriers to airborne pollen in the form of treehedges orientated at $90^{\circ}$ to the prevailing wind in field groups 3 and 13.) To our knowledge, this is the first study to provide quantitative evidence to support the view that flowing water can cause directional gene flow and thereby help preserve the genetic substructuring of a plant population.

\section{Acknow ledgements}

We are grateful to Jane Squirrell for assistance in the field and laboratory; to Susan Wilson for discussions on the species composition and water chemistry of the ditches; and to Tony Robinson (English Nature) for permission to collect pondweed samples and for information on the past history and management of the Gordano Valley nature reserve.

\section{References}

BARRETT, S. C. H., ECKERT, C. G. AND HUSBAND, B. C. 1993. Evolutionary processes in aquatic plant populations. Aquat. Bot., 44, 105-145.

Beltman, B. 1984. Management of ditches. The effect of cleaning ditches on the water coenoses. Verh. Int. Verein. Limnol., 22, 2022-2028.

COOK, C. D. K. 1985. Range extensions of aquatic vascular plant species. J. Aquat. Plant Management, 23, 1-6.

HeAthwaite, A. L. 1990. Gordano Valley SSSI: Preliminary Hydrological Survey. Unpublished report, Nature Conservancy Council.

HILl, R. J., PRANCE, G. T., MORI, S. A., STEWARD, W. C., SHIMABUKURU, D. AND BERBARDI, J. 1978. Estudo electroforético da dinâmica de variação genética em três taxa ribeirinhus ao longo do rio Solimões, América do Sul. Acta Amazonica, 8, 183-199.

HOLLINGSWORTH, P. M., GORNALL, R. J. AND PRESTON, C. D. 1995. Genetic variability in British populations of Potamogeton coloratus (Potamogetonaceae). Pl. Syst. Evol., 197, 71-85.

HOLLINGSWORTH, P. M., PRESTON, C. D. AND GORNALL, R. J. 1996. Genetic variability in two hydrophilous species of Potamogeton, P. pectinatus and $P$. filiformis (Potamogetonaceae). Pl. Syst. Evol., 202, 233-254.

IBRAHIM, K. M., NICHOLS, R. A. AND HEWITT, G. M. 1996. Spatial patterns of genetic variation generated by different forms of dispersal during range expansion. Heredity, 77, 282-291.
JEFFERIES, R. L., WILlis, A. J. AND YeMM, E. W. 1968. The late- and post-glacial history of the Gordano Valley, North Somerset. New Phytol., 67, 335-348.

KIMURA, M. 1968. Evolutionary rate at the molecular level. Nature, 217, 624-626.

Laushman, R. H. 1993. Population genetics of hydrophilous angiosperms. Aquat. Bot., 44, 147-158.

LEVENE, H. 1949. On a matching problem arising in genetics. Ann. Math. Stat., 20, 91-94.

LOKKER, C., SUSKO, D., LOVETT DOUST, L. AND LOVETT DOUST, J. 1994. Population genetic structure of Vallisneria americana, a dioecious clonal macrophyte. Am. J. Bot., 81, 1004-1012.

McCAuley, D. E. 1991. Genetic consequences of local population extinction and recolonization. Trends Ecol. Evol., 6, 5-8.

NEI, M. 1975. Molecular Population Genetics and Evolution. North Holland Publishing Co., Amsterdam.

NEI, M. 1977. $F$-statistics and analysis of gene diversity in subdivided populations. Ann. Hum. Genet., 41, 225-233.

NEI, M. AND IMAIZUMI, Y. 1966. Genetic structure of human populations. II. Differentiation of blood group gene frequencies among isolated populations. Heredity, 21, 183-190.

RIDLEY, H. N. 1930. Dispersal of Plants Throughout the World. L. Reeve \& Co., Ashford, Kent.

RITLAND, K. 1989. Genetic differentiation, diversity, and inbreeding in the mountain monkey-flower (Mimulus caespitosus) of the Washington Cascades. Can. J. Bot., 67, 2017-2024.

RUCKELSHAUS, M. H. 1996. Estimation of genetic neighbourhood parameters from pollen and seed dispersal in the marine angiosperm Zostera marina L. Evolution, 50, 856-864.

SWOFFORD, D. L. AND SElANDER, R. B. 1981. Biosys-1. University of Illinois, Urbana, IL.

VlAMING, v. DE AND PROCTOR, v. w. 1968. Dispersal of aquatic organisms: viability of seeds recovered from the droppings of captive killdeer and mallard ducks. Am. J. Bot., 55, 20-26.

WILlis, A. J. AND JEFFERIES, R. L. 1959. The plant ecology of the Gordano valley. Proc. Bristol Naturalists' Soc., 29, 469-490.

WORKMAN, P. L. AND NISWANDER, J. D. 1970. Population studies on southwest Indian tribes. II. Local genetic differentiation in the Papago. Am. J. Hum. Genet., 22, 24-29.

WRIGHT, s. 1965. The interpretation of population structure by $F$-statistics with special regard to systems of mating. Evolution, 19, 395-420.

Wright, s. 1978. Evolution and Genetics of Populations, vol. 4, Variability Within and Among Populations. University of Chicago Press, Chicago. 